\title{
TITLE:
}

\section{Degeneration of Period Matrices of Stable Curves(Abstract_要旨)}

$\operatorname{AUTHOR}(\mathrm{S})$ :

Yu, Yang

\section{CITATION:}

Yu, Yang. Degeneration of Period Matrices of Stable Curves. 京都大学, 2017, 博士(理学)

ISSUE DATE:

2017-03-23

URL:

https://doi.org/10.14989/doctor.k20160

\section{RIGHT:}

学位規則第9条第2項により要約公開; 許諾条件により本文は2019-0701に公開 


\begin{tabular}{|l|c|l|l|}
\hline 京都大学 & 博士（理 学） & 氏名 & 陽 煜 \\
\hline 論文題目 & $\begin{array}{l}\text { Degeneration of Period Matrices of Stable Curves } \\
\text { (安定曲線に付随する周期行列の退化性について) }\end{array}$ \\
\hline
\end{tabular}

(論文内容の要旨)

通常の遠アーベル幾何では、数論的な体の上で定義された代数多様体を扱い、その代 数多様体に付随する幾何的基本群への基礎体のガロア群の外作用から出発して与えら れた代数多様体の幾何的性質をどの程度において復元することが可能であるか、と いったような問題が中心的なテーマになるわけだが、それに対して組合せ論的遠ア一 ベル幾何では、標数ゼロの代数閉体の上で定義された（多くの場合、双曲的代数曲線 に関連した）設定において、

その設定の組合せ論的・幾何的性質がどの程度において設定に付随する

(幾何的副有限) 基本群の群論的性質に反映されるか、

といったような問題が主たる考察の対象となる。代表的な例として、「遠アーベル体 の半グラフ」（semi-graph of anabelioids）への（双曲的代数曲線の退化から生じ る）惰性群の作用が与えられたとき、様々な条件の下でその半グラフの組合せ論的幾 何を、遠アーベル体の半グラフに付随する副有限基本群への（与えられた）惰性群の 外作用から復元するという、「組合せ論的グロタンディーク予想（CombGC）」が挙げ られる。

これまで様々な種類のCombGCが得られているが、最も基本的な種類のCombGCでは、 扱っている双曲的代数曲線の退化から生じる「周期行列」という不変量の非退化性が 重要な役割を果たす。任意の種類の退化に対してこの周期行列の非退化性を示すこと が仮にもしも可能だと仮定すると、非常に強い形のCombGCを示すことが可能になる が、実際には（数体上の固有双曲的代数曲線に付随する外ガロア表現の単射性等）重 要な応用では、所望の周期行列の非退化性が成立しない場合も知られている。このよ うな状況を踏まえて考えると、

与えられた双曲的代数曲線の退化に付随する周期行列がどのような条件の 下で非退化になるか、

といったような問い掛けが一つの本質的な未解決問題として浮上するわけだが、陽氏 の学位論文の主定理、つまり、双曲的代数曲線の退化に対して、

付随する半グラフから自己交差するすべての辺を除去することによって得られ る半グラフの非可縮性が、退化な周期行列を生じる「群論的に非退化な退化」 の存在性と同值である

という結果によって、上記の未解決問題に対する決定的な解決が与えられたことにな る。論文では、与えられた退化な双曲的代数曲線の様々な変形や部分曲線をとること によって、問題の周期行列を「ブロック化」し、その行列式を容易に計算できるよう な形のものに書き直すことによって主定理を証明している。 
(続紙 2 )

(論文審査の結果の要旨)

陽氏の学位論文の主定理の証明は最終的には、与えられた退化な双曲的代数曲線の 変形や部分曲線への移行によって比較的単純な「ブロック化」された形の行列の行 列式の計算に帰着するという形で行なわれるわけだが、この研究の初期の段階で は、そのような簡単な計算も、定理の適切かつ簡明な定式化もなかった。つまり、 研究の初期の段階では、陽氏は実に膨大な量の具体例の計算を行なった上で、それ らの具体例に発生している組合せ論的現象の本質を直観的なレベルで理解し、その 直感を様々な具体例の場合に（指導教員である）望月に詳しく解説した。この解説 を受けて望月は一種の「作業仮説」ないしは「予想」として最終的な主定理となっ た定式化を提案したわけだが、そのような一般的な形では証明はかなり困難である 可能性が高く、恐らく長期的な目標のようなものして考えるべきではないか、と感 想を述べたところ、二二週間も経たないうちに、陽氏はその「作業仮説・予想」 を、自力で、しかもほぼ完全な形で証明することに成功した。この見事な「研究の 作業過程」も、陽氏の今回の研究の特筆す心゙き一面として挙げるべきであろう。

今回の論文の主定理によって、双曲的代数曲線の退化に付随する周期行列の非退化 性に関する決定的な「純組合せ論的」特徵付け（＝つまり、付随する半グラフのみ によって定まる特徵付け）が与えられたことになり、博士課程の大学院生の手によ るものとしてはそれなりに高い評価に值するものと認められる。この主定理を、い わゆる「モノドロミ一予想」の一種の組合せ論版に対する反例として解釈できると ころも興味深い。

よって、本論文は博士（理学）の学位論文として価值あるものと認める。また、平 成 29 年 1 月 13 日、論文内容とそれに関連した事項について試問を行なった結 果、合格と認めた。 